\title{
HAK ATAS KEKAYAAN INTELEKTUAL DALAM PRODUK STUDY KASUS PRODUK APPLE
}

\author{
Erina Oktarini \\ 155100027, 785567840 \\ Fakultas Komputer \\ erinaoktarini.student@umitra.ac.id
}

\begin{abstract}
Hak Atas Kekayaan Intelektual adalah hak eksklusif yang diberikan suatu hukum atau peraturan kepada seseorang atau sekelompok orang atas karya ciptanya. Menurut UU yang telah disahkan oleh DPR-RI pada tanggal 21 Maret 1997, Haki adalah hak-hak secara hukum yang berhubungan dengan permasalahan hasil penemuan dan kreativitas seseorang atau beberapa orang yang berhubungan dengan perlindungan permasalahan reputasi dalam bidang komersial (commercial reputation) dan tindakan / jasa dalam bidang komersial (goodwill).

Dengan begitu obyek utama dari Haki adalah karya, ciptaan, hasil buah pikiran, atau intelektualita manusia. Kata "intelektual" tercermin bahwa obyek kekayaan intelektual tersebut adalah kecerdasan, daya pikir, atau produk pemikiran manusia (the Creations of the Human Mind) (WIPO, 1988:3). Setiap manusia memiliki memiliki hak untuk melindungi atas karya hasil cipta, rasa dan karsa setiap individu maupun kelompok.
\end{abstract}

Kata Kunci : HAKI 


\section{A. INTRODUCTION}

Hak Atas Kekayaan Intelektual adalah hak eksklusif yang diberikan suatu hukum atau peraturan kepada seseorang atau sekelompok orang atas karya ciptanya. Menurut UU yang telah disahkan oleh DPR-RI pada tanggal 21 Maret 1997, HaKI adalah hak-hak secara hukum yang berhubungan dengan permasalahan hasil penemuan dan kreativitas seseorang atau beberapa orang yang berhubungan dengan perlindungan permasalahan reputasi dalam bidang komersial (commercial reputation) dan tindakan / jasa dalam bidang komersial (goodwill).

Dengan begitu obyek utama dari HaKI adalah karya, ciptaan, hasil buah pikiran, atau intelektualita manusia. Kata "intelektual" tercermin bahwa obyek kekayaan intelektual tersebut adalah kecerdasan, daya pikir, atau produk pemikiran manusia (the Creations of the Human Mind) (WIPO, 1988:3). Setiap manusia memiliki memiliki hak untuk melindungi atas karya hasil cipta, rasa dan karsa setiap individu maupun kelompok.
Kita perlu memahami HaKI untuk menimbulkan kesadaran akan pentingnya daya kreasi dan inovasi intelektual sebagai kemampuan yang perlu diraih oleh setiap manusia, siapa saja yang ingin maju sebagai faktor pembentuk kemampuan daya saing dalam penciptaan Inovasi-inovasi yang kreatif.

\section{Prinsip-prinsip Hak Kekayaan Intelektual}

Prinsip-prinsip Hak atas Kekayaan Intelektual (HaKI) adalah sebagai berikut :

\section{Prinsip Ekonomi}

Dalam prinsip ekonomi, hak intelektual berasal dari kegiatan kreatif dari daya pikir manusia yang memiliki manfaat serta nilai ekonomi yang akan member keuntungan kepada pemilik hak cipta.

- Prinsip Keadilan

Prinsip keadilan merupakan suatu perlindungan hukum bagi pemilik suatu hasil dari kemampuan intelektual, sehingga memiliki 
kekuasaan dalam penggunaan hak atas kekayaan intelektual terhadap karyanya.

- Prinsip Kebudayaan

Prinsip kebudayaan merupakan pengembangan dari ilmu pengetahuan, sastra dan seni guna meningkatkan taraf kehidupan serta akan memberikan keuntungan bagi masyarakat, bangsa dan Negara.

\section{- Prinsip Sosial}

Prinsip sosial mengatur kepentingan manusia sebagai warga Negara, sehingga hak yang telah diberikan oleh hukum atas suatu karya merupakan satu kesatuan yang diberikan perlindungan berdasarkan keseimbangan antara kepentingan individu dan masyarakat/ lingkungan.

Secara umum Hak atas Kekayaan Intelektual (HaKI) terbagi dalam dua kategori, yaitu :

1. Hak Cipta

2. Hak Kekayaan Industri, yang meliputi :

1. Hak Paten
2. Hak Merek

3. Hak Desain Industri

4. Hak Desain Tata Letak Sirkuit Terpadu

5. Hak Rahasia Dagang

6. Hak Indikasi

Apple Inc., perusahaan komputer terkemuka yang berpusat di Cupertino, California, kembali harus menelan kekecewaan. Kali ini bukan gara-gara sengketa HKI mereka dengan Samsung, melainkan karena komisi banding kantor merek Amerika Serikat, USPTO, baru saja memperkuat putusan USPTO sebelumnya untuk menolak pendaftaran merek yang diajukan Apple atas kata "multitouch".

Upaya Apple untuk

memperoleh monopoli dalam bentuk pendaftaran merek atas kata "multitouch" jelas-jelas termotivasi oleh sukses produk-produk mereka yang menampilkan fitur "multi-touch" di pasaran, $\quad$ seperti iPhone, iPod Touch dan iPad. Namun rupanya USPTO tidak semudah itu menerima logika bahwa manakala suatu kata 
telah sedemikian rupa diasosiasikan dengan suatu produk yang sangat sukses di pasaran, maka kata tersebut telah memperoleh "daya pembeda" terkait dengan produk tersebut.

Untuk bisa mendapatkan perlindungan sebagai merek terdaftar, suatu kata/frasa memang sudah harus memiliki daya pembeda (acquired distinctiveness) yang mampu menjadi penanda dari mana produk yang terwakili oleh kata tersebut berasal (indication of origin of goods/services); dan bukan kata/frasa yang semata-mata hanya bersifat deskriptif, yaitu memberi gambaran mengenai produk yang diwakilinya (mere descriptiveness).

Berdasarkan prinsip tersebut, USPTO memandang bahwa frasa "multitouch" memang cukup deskriptif dalam menggambarkan teknologi fiturfitur pinching, zooming, swiping, dan scrolling yang dihadirkan dalam produk-produk Apple, akan tetapi frasa yang sama juga deskriptif untuk fiturfitur yang dimiliki produk-produk yang berasal dari produsen lain. Dengan demikian, “deskriptif”-nya frasa tersebut justru membuat Apple gagal dalam meyakinkan bahwa frasa "multi-touch" sendiri cukup mengandung "daya pembeda" yang menunjukkan Apple sebagai asal-usul dari produk tersebut.

Saat ini Apple juga tengah harap-harap cemas menantikan sikap USPTO dan juga pengadilan terkait dengan perlindungan merek terhadap kata "AppStore". Mengingat proses yang masih cukup panjang dan berliku, tampaknya baru pertengahan tahun depan Apple bisa mengetahui apakah "AppStore" sekedar kata yang deskriptif atau sudah memiliki daya pembeda.

\section{B. CONTENT}

Apple Inc., perusahaan komputer terkemuka yang berpusat di Cupertino, California, kembali harus menelan kekecewaan. Kali ini bukan gara-gara sengketa HKI mereka dengan Samsung, melainkan karena komisi banding kantor merek Amerika Serikat, USPTO, baru saja memperkuat putusan USPTO sebelumnya untuk menolak pendaftaran merek yang 
diajukan Apple atas kata "multitouch".

Upaya Apple untuk memperoleh monopoli dalam bentuk pendaftaran merek atas kata "multi-touch" jelasjelas termotivasi oleh sukses produkproduk mereka yang menampilkan fitur "multi-touch" di pasaran, seperti iPhone, iPod Touch dan iPad. Namun rupanya USPTO tidak semudah itu menerima logika bahwa manakala suatu kata telah sedemikian rupa diasosiasikan dengan suatu produk yang sangat sukses di pasaran, maka kata tersebut telah memperoleh "daya pembeda" terkait dengan produk tersebut.

Untuk bisa mendapatkan perlindungan sebagai merek terdaftar, suatu kata/frasa memang sudah harus memiliki daya pembeda (acquired distinctiveness) yang mampu menjadi penanda dari mana produk yang terwakili oleh kata tersebut berasal (indication of origin of goods/services); dan bukan kata/frasa yang semata-mata hanya bersifat deskriptif, yaitu memberi gambaran mengenai produk yang diwakilinya (mere descriptiveness).
Berdasarkan prinsip tersebut, USPTO memandang bahwa frasa "multitouch" memang cukup deskriptif dalam menggambarkan teknologi fiturfitur pinching, zooming, swiping, dan scrolling yang dihadirkan dalam produk-produk Apple, akan tetapi frasa yang sama juga deskriptif untuk fiturfitur yang dimiliki produk-produk yang berasal dari produsen lain. Dengan demikian, “deskriptif”-nya frasa tersebut justru membuat Apple gagal dalam meyakinkan bahwa frasa "multi-touch" sendiri cukup mengandung "daya pembeda" yang menunjukkan Apple sebagai asal-usul dari produk tersebut.

Saat ini Apple juga tengah harap-harap cemas menantikan sikap USPTO dan juga pengadilan terkait dengan perlindungan merek terhadap kata "AppStore". Mengingat proses yang masih cukup panjang dan berliku, tampaknya baru pertengahan tahun depan Apple bisa mengetahui apakah "AppStore" sekedar kata yang deskriptif atau sudah memiliki daya pembeda. 


\section{CONCLUSION}

Prinsip-prinsip Hak atas Kekayaan Intelektual (HaKI) adalah sebagai berikut :

\section{Prinsip Ekonomi}

Dalam prinsip ekonomi, hak intelektual berasal dari kegiatan kreatif dari daya pikir manusia yang memiliki manfaat serta nilai ekonomi yang akan member keuntungan kepada pemilik hak cipta.

\section{- Prinsip Keadilan}

Prinsip keadilan merupakan suatu perlindungan hukum bagi pemilik suatu hasil dari kemampuan intelektual, sehingga memiliki kekuasaan dalam penggunaan hak atas kekayaan intelektual terhadap karyanya.

\section{- Prinsip Kebudayaan}

Prinsip kebudayaan merupakan pengembangan dari ilmu pengetahuan, sastra dan seni guna meningkatkan taraf kehidupan serta akan memberikan keuntungan bagi masyarakat, bangsa dan Negara.

\section{- Prinsip Sosial}

Prinsip sosial mengatur kepentingan manusia sebagai warga Negara, sehingga hak yang telah diberikan oleh hukum atas suatu karya merupakan satu kesatuan yang diberikan perlindungan berdasarkan keseimbangan antara kepentingan individu dan masyarakat/ lingkungan.

Secara umum Hak atas Kekayaan Intelektual (HaKI) terbagi dalam dua kategori, yaitu :

\section{Hak Cipta}

4. Hak Kekayaan Industri, yang meliputi :

1. Hak Paten

2. Hak Merek

3. Hak Desain Industri

4. Hak Desain Tata Letak Sirkuit Terpadu

5. Hak Rahasia Dagang

6. Hak Indikasi

Apple Inc., perusahaan komputer terkemuka yang berpusat di Cupertino, 
California, kembali harus menelan kekecewaan. Kali ini bukan gara-gara sengketa HKI mereka dengan Samsung, melainkan karena komisi banding kantor merek Amerika Serikat, USPTO, baru saja memperkuat putusan USPTO sebelumnya untuk menolak pendaftaran merek yang diajukan Apple atas kata "multitouch".

Upaya Apple untuk

memperoleh monopoli dalam bentuk pendaftaran merek atas kata "multitouch" jelas-jelas termotivasi oleh sukses produk-produk mereka yang menampilkan fitur "multi-touch" di pasaran, seperti iPhone, iPod

Touch dan iPad. Namun rupanya USPTO tidak semudah itu menerima logika bahwa manakala suatu kata telah sedemikian rupa diasosiasikan dengan suatu produk yang sangat sukses di pasaran, maka kata tersebut telah memperoleh "daya pembeda" terkait dengan produk tersebut.

Untuk bisa mendapatkan perlindungan sebagai merek terdaftar, suatu kata/frasa memang sudah harus memiliki daya pembeda (acquired distinctiveness) yang mampu menjadi penanda dari mana produk yang terwakili oleh kata tersebut berasal (indication of origin of goods/services); dan bukan kata/frasa yang semata-mata hanya bersifat deskriptif, yaitu memberi gambaran mengenai produk yang diwakilinya (mere descriptiveness).

Berdasarkan prinsip tersebut, USPTO memandang bahwa frasa "multitouch" memang cukup deskriptif dalam menggambarkan teknologi fiturfitur pinching, zooming, swiping, dan scrolling yang dihadirkan dalam produk-produk Apple, akan tetapi frasa yang sama juga deskriptif untuk fiturfitur yang dimiliki produk-produk yang berasal dari produsen lain. Dengan demikian, “deskriptif”-nya frasa tersebut justru membuat Apple gagal dalam meyakinkan bahwa frasa "multi-touch" sendiri cukup mengandung "daya pembeda" yang menunjukkan Apple sebagai asal-usul dari produk tersebut.

Saat ini Apple juga tengah harap-harap cemas menantikan sikap USPTO dan juga pengadilan terkait dengan perlindungan merek terhadap kata 
"AppStore". Mengingat proses yang masih cukup panjang dan berliku, tampaknya baru pertengahan tahun depan Apple bisa mengetahui apakah "AppStore" sekedar kata yang deskriptif atau sudah memiliki daya pembeda.

\section{DISCUSSION}

Prinsip-prinsip Hak atas Kekayaan Intelektual (HaKI) adalah sebagai berikut :

\section{Prinsip Ekonomi}

Dalam prinsip ekonomi, hak intelektual berasal dari kegiatan kreatif dari daya pikir manusia yang memiliki manfaat serta nilai ekonomi yang akan member keuntungan kepada pemilik hak cipta.

- Prinsip Keadilan

Prinsip keadilan merupakan suatu perlindungan hukum bagi pemilik suatu hasil dari kemampuan intelektual, sehingga memiliki kekuasaan dalam penggunaan hak atas kekayaan intelektual terhadap karyanya.

- Prinsip Kebudayaan

Prinsip kebudayaan merupakan pengembangan dari ilmu pengetahuan, sastra dan seni guna meningkatkan taraf kehidupan serta akan memberikan keuntungan bagi masyarakat, bangsa dan Negara.

- Prinsip Sosial

Prinsip sosial mengatur kepentingan manusia sebagai warga Negara, sehingga hak yang telah diberikan oleh hukum atas suatu karya merupakan satu kesatuan yang diberikan perlindungan berdasarkan keseimbangan antara kepentingan individu dan masyarakat/ lingkungan.

Secara umum Hak atas Kekayaan Intelektual (HaKI) terbagi dalam dua kategori, yaitu :

5. Hak Cipta

6. Hak Kekayaan Industri, yang meliputi :

1. Hak Paten

2. Hak Merek 
3. Hak Desain Industri

4. Hak Desain Tata Letak Sirkuit Terpadu

5. Hak Rahasia Dagang

6. Hak Indikasi

Apple Inc., perusahaan komputer terkemuka yang berpusat di Cupertino, California, kembali harus menelan kekecewaan. Kali ini bukan gara-gara sengketa HKI mereka dengan Samsung, melainkan karena komisi banding kantor merek Amerika Serikat, USPTO, baru saja memperkuat putusan USPTO sebelumnya untuk menolak pendaftaran merek yang diajukan Apple atas kata "multitouch".

\section{Upaya Apple untuk}

memperoleh monopoli dalam bentuk pendaftaran merek atas kata "multitouch" jelas-jelas termotivasi oleh sukses produk-produk mereka yang menampilkan fitur "multi-touch" di pasaran, seperti iPhone, iPod Touch dan iPad. Namun rupanya USPTO tidak semudah itu menerima logika bahwa manakala suatu kata telah sedemikian rupa diasosiasikan dengan suatu produk yang sangat sukses di pasaran, maka kata tersebut telah memperoleh "daya pembeda" terkait dengan produk tersebut.

Untuk bisa mendapatkan perlindungan sebagai merek terdaftar, suatu kata/frasa memang sudah harus memiliki daya pembeda (acquired distinctiveness) yang mampu menjadi penanda dari mana produk yang terwakili oleh kata tersebut berasal (indication of origin of goods/services); dan bukan kata/frasa yang semata-mata hanya bersifat deskriptif, yaitu memberi gambaran mengenai produk yang diwakilinya (mere descriptiveness).

Berdasarkan prinsip tersebut, USPTO memandang bahwa frasa "multitouch" memang cukup deskriptif dalam menggambarkan teknologi fiturfitur pinching, zooming, swiping, dan scrolling yang dihadirkan dalam produk-produk Apple, akan tetapi frasa yang sama juga deskriptif untuk fiturfitur yang dimiliki produk-produk yang berasal dari produsen lain. Dengan demikian, “deskriptif”-nya frasa tersebut justru membuat Apple gagal dalam meyakinkan bahwa frasa 
"multi-touch" sendiri cukup

mengandung "daya pembeda" yang menunjukkan Apple sebagai asal-usul dari produk tersebut.

Saat ini Apple juga tengah harap-harap cemas menantikan sikap USPTO dan juga pengadilan terkait dengan perlindungan merek terhadap kata "AppStore". Mengingat proses yang masih cukup panjang dan berliku, tampaknya baru pertengahan tahun depan Apple bisa mengetahui apakah "AppStore" sekedar kata yang deskriptif atau sudah memiliki daya pembeda.

\section{E. REFERENCE}

[1] O. M. Febriani and A. S. Putra, "Sistem Informasi Monitoring Inventori Barang Pada Balai Riset Standardisasi Industri Bandar Lampung," J. Inform., vol. 13, no. 1, pp. 90-98, 2014.

[2] A. S. Putra, "Paperplain: Execution Fundamental Create Application With Borland Delphi 7.0 University Of Mitra Indonesia," 2018.

[3] A. S. Putra, "2018 Artikel Struktur Data, Audit Dan Jaringan Komputer," 2018.

[4] A. S. Putra, "ALIAS MANAGER USED IN DATABASE DESKTOP STUDI CASE DB DEMOS."
[5] A. S. Putra, "COMPREHENSIVE SET OF PROFESSIONAL FOR DISTRIBUTE COMPUTING."

[6] A. S. Putra, "DATA ORIENTED RECOGNITION IN BORLAND DELPHI 7.0."

[7] A. S. Putra, "EMBARCADERO DELPHI XE 2 IN GPUPOWERED FIREMONKEY APPLICATION."

[8] A. S. Putra, "HAK ATAS KEKAYAAN INTELEKTUAL DALAM DUNIA TEKNOLOGY BERBASIS REVOLUSI INDUSTRI 4.0.”

[9] A. S. Putra, "IMPLEMENTASI PERATURAN

PERUNDANGAN UU. NO 31

TAHUN $2000 \quad$ TENTANG

DESAIN INDUSTRI

BERBASIS INFORMATION TECHNOLOGY."

[10] A. S. Putra, "IMPLEMENTATION OF PARADOX DBASE."

[11] A. S. Putra, "IMPLEMENTATION OF TRADE SECRET CASE STUDY SAMSUNG MOBILE PHONE."

[12] A. S. Putra, "IMPLEMENTATION PATENT FOR APPLICATION WEB BASED CASE STUDI WWW. PUBLIKLAMPUNG. COM."

[13]

A. S. Putra, "IMPLEMENTATION SYSTEM FIRST TO INVENT IN DIGITALLY INDUSTRY."

[14] A. S. Putra, "MANUAL REPORT \& INTEGRATED DEVELOPMENT

ENVIRONMENT BORLAND 
DELPHI 7.0."

[15] A. S. Putra, "PATENT AS RELEVAN SUPPORT RESEARCH."

[16] A. S. Putra, "PATENT FOR RESEARCH STUDY CASE OF APPLE. Inc."

[17] A. S. Putra, "PATENT PROTECTION FOR APPLICATION INVENT."

[18] A. S. Putra, "QUICK REPORT IN PROPERTY PROGRAMMING."

[19] A. S. Putra, "REVIEW CIRCUIT LAYOUT COMPONENT

REQUIREMENT ON ASUS NOTEBOOK."

[20] A. S. Putra, "REVIEW TRADEMARK PATENT FOR INDUSTRIAL TECHNOLOGY BASED 4.0."

[21] A. S. Putra, "TOOLBAR COMPONENT PALLETTE IN OBJECT ORIENTED PROGRAMMING."

[22] A. S. Putra, "WORKING DIRECTORY SET FOR PARADOX 7."

[23] A. S. Putra, "ZQUERY CONNECTION IMPLEMENTED

PROGRAMMING STUDI CASE PT. BANK BCA Tbk."

[24] A. S. Putra, D. R. Aryanti, and I. Hartati, "Metode SAW (Simple Additive Weighting) sebagai Sistem Pendukung Keputusan Guru Berprestasi (Studi Kasus: SMK Global Surya)," in Prosiding Seminar Nasional Darmajaya, 2018, vol. 1, no. 1, pp. 85-97.

[25] A. S. Putra and O. M. Febriani, "Knowledge Management
Online Application in PDAM Lampung Province," in Prosiding International conference on Information Technology and Business (ICITB), 2018, pp. 181-187.

[26] A. S. Putra, O. M. Febriani, and B. Bachry, "Implementasi Genetic Fuzzy System Untuk Mengidentifikasi Hasil Curian Kendaraan Bermotor Di Polda Lampung," SIMADA (Jurnal Sist. Inf. dan Manaj. Basis Data), vol. 1, no. 1, pp. 21-30, 2018.

[27] A. S. Putra, H. Sukri, and K. Zuhri, "Sistem Monitoring Realtime Jaringan Irigasi Desa (JIDES) Dengan Konsep Jaringan Sensor Nirkabel," IJEIS (Indonesian J. Electron. Instrum. Syst., vol. 8, no. 2, pp. 221-232.

[28] D. P. Sari, O. M. Febriani, and A. S. Putra, "Perancangan Sistem Informasi SDM Berprestasi pada SD Global Surya," in Prosiding Seminar Nasional Darmajaya, 2018, vol. 1, no. 1, pp. 289-294. 